\title{
Archiwa i archiwalia prywatne w zasobie Archiwum Państwowego w Szczecinie
}

Archiwalia proweniencji prywatnej w zasobie szczecińskiego archiwum posiadają dość długą metrykę, sięgającą połowy XIX w., czasów działania Pruskiego Królewskiego Archiwum Prowincjonalnego w Szczecinie (Preussisches Königliches Provinzial-Archiv zu Stettin). Wówczas na podstawie zarządzenia premiera rządu pruskiego Otto Manteuffla z 1855 r. szczecińska placówka została zobowiązana do przyjęcia w depozyt zbiory historyczne działającego od 1824 r. Pomorskiego Towarzystwa Historii i Starożytności Pomorza (Gesellschaft für Pommersche Geschichte und Altertumskunde) ${ }^{1}$. Materiały te stały się podstawą niepaństwowego zasobu archiwalnego w szczecińskim archiwum. Były to przede wszystkim kolekcje dokumentów i archiwaliów od średniowiecza do XIX w., zgromadzone przez pomorskich kolekcjonerów i badaczy przeszłości, m.in. Samuela Gottlieba Loepera czy Wilhelm Friedrich i Johanna Christopha Adelungów².

Przez kolejne dziewięćdziesiąt lat, do 1945 r. szczecińska placówka, od 1867 r. pod nazwą Pruskiego Królewskiego Archiwum Państwowego w Szcze-

${ }^{1}$ L. Turek-Kwiatkowska, Z dziejów stużby archiwalnej. Archiwa na Pomorzu Zachodnim w latach 1808-1914, Warszawa 1968, s. 141-142; M. Szukała, Powstanie i działalność Towarzystwa Historii i Starożytności Pomorza w Szczecinie w latach 1824-1918, Szczecin 2000, s. 101-102. Zobacz też: Archiwum Państwowe w Szczecinie (dalej AP Szczecin), Archiwum Państwowe w Szczecinie (Staatsarchiv Stettin, dalej APS), sygn. 809.

2 Zbiór Loepera został przekazany w 1834 r. przez spadkobierców kolekcjonera Pomorskiemu Towarzystwu Historii i Starożytności w Szczecinie. Po 1855 r. w zasobie Archiwum materiały te tworzyły odrębny zbiór-depozyt (Rep. 38f Loepersche Sammlung). Podobnie było ze spuścizną Adelungów (Rep. 38f Adelung). Archiwum Państwowe w Szczecinie. Przewodnik po zasobie archiwalnym. Akta do 1945 roku, oprac. R. Gaziński, P. Gut, M. Szukała, Warszawa-Szczecin 2002, s. 476-478; M. Szukała, Powstanie i działalność, s. 96-98. 
cinie (Preussisches Königliches Staatsarchiv Stettin), przyjęła kilkadziesiąt kolejnych spuścizn i kolekcji naukowych, m.in. Juliusa Bohlena, Karla Loewego, Hansa Lutscha oraz Martina Wehrmanna ${ }^{3}$.

Od lat siedemdziesiątych XIX w. w ramach rozszerzania zainteresowania środowisk naukowych na kolejne grupy archiwaliów, proweniencji komunalnej, kościelnej, a także rodzinno-majątkowej, materiały te zaczęły pojawiać się w zasobie Archiwum Państwowego w Szczecinie. Pierwsze z nich przyjmowane były na podstawie ogólnej umowy między Sejmikiem Prowincji Pomorskiej (Pommerscher Landtag), choć każde z miast pomorskich przekazywało dokumentację komunalną na podstawie odrębnej umowy depozyto$w^{4} j^{4}$. Te ostatnie sporządzanie były również przy przejęciu archiwaliów od miejscowych rodów szlacheckich i ziemiańskich. Jednym z pierwszych rodowych archiwów był depozyt znanej pomorskiej arystokratycznej rodziny von Eickstedt w 1888 r. ${ }^{5}$ Do początku lat czterdziestych XX w. archiwum w Szczecinie posiadało w swym zasobie w formie depozytów i przejętych na własność spuścizny pięćdziesięciu rodzin szlacheckich, wielkich właścicieli ziemskich, w tym: von Borcke, von Dewitz (cztery archiwa) ${ }^{6}$, von Eickstedt, von Eckenvorth, von der Goltz, von Lepel, von Maltzahn, von Podewils, von Puttkammer, von Steinwehr, von Zitzewitz (dwa archiwa) ${ }^{7}$.

Napływ spuścizn rodowych, a także przejęcia kolejnych materiałów kolekcjonerskich i spuścizn naukowych w okresie dwudziestolecia międzywojennego XX w. wiązał się również intensywnymi działaniami władz archiwalnych oraz Komisji Historycznej dla Pomorza (Historische Kommission für Pommern) w celu zewidencjonowania i zabezpieczenia archiwów i archiwaliów niepaństwowych ${ }^{8}$.

${ }^{3}$ AP Szczecin, APS, sygn. 785, 1593, 1917. Zob. L. Turek-Kwiatkowska, Z dziejów stużby, s. 136-140. Archiwum Państwowe w Szczecinie. Przewodnik, s. 470-483.

${ }^{4}$ AP Szczecin, APS, sygn. 477-478; L. Turek-Kwiatkowska, Z dziejów stużby, s. 122-128.

${ }^{5}$ AP Szczecin, APS, sygn. 490. W $1897 \mathrm{r}$. akta zdeponowała rodzina von Maltzahn, w $1904 \mathrm{r}$. von Puttkammer, a w 1917 r. von Zitzewitz. Depozyty rodowe były przekazywane do czasów II wojny światowej, np. rodu von Goltz w 1939 r. AP Szczecin, APS, sygn. 497 (Maltzahn), 521 (Puttkammer), 557 (Zitzewitz), 324 (Goltz); L. Turek-Kwiatkowska, Z dziejów stużby, s. 143145.

${ }^{6} \mathrm{~W}$ zasobie Archiwum Państwowego w Szczecinie przechowywanych jest 5 zespołów o nazwie (zespoły 65/17-65/21) Archiwum rodu von Dewitz-... (Patrz załącznik nr 1), ale $4 \mathrm{z}$ nich (65/17-65/20) stanowią archiwa rodowe, natomiast (65/21) Archiwum rodu von Dewitz-Ganzer jest zbiorem materiałów roboczych (notatki, wypisy źródłowe, tablice genealogiczne) profesora Paula Ganzera, który powstał w trakcie pracy nad monografią rodziny von Dewitz (P. Gantzer, Geschichte der Familie von Dewitz. Bd. 1-3, Halle 1912-1918). Zbiór ten prof. Paul Ganzer po napisaniu monografii rodowej oddał rodzinie von Dewitz, a ta przekazała go w depozyt do archiwum w Szczecinie.

${ }^{7}$ A. Diestelkamp, Das Staatsarchiv Stettin seit dem Weltkriege, ,"Monatsblätter der Gesellschaft für pommersche Geschichte und Alterthumskunde“ 1938, Jg. 52, H. 4, s. 77.

${ }^{8}$ Szerzej na ten temat: M. Szukała, Formy ochrony dokumentacji nieurzędowej w Archiwum Państwowym w Szczecinie (Staatsarchiv Stettin) w XIX i pierwszej potowie XX wieku, artykuł w niniejszym tomie. 
W okresie II wojny światowej spuścizny rodowe, archiwa prywatne i kolekcje, będące w zasobie pruskiego Archiwum Państwowego w Szczecinie, podobnie jak większość archiwaliów tej placówki zostały rozśrodkowane celem zabezpieczenia przed zniszczeniem w trakcie nalotów bombowych na miasto. Miejscami ewakuacji były dwory i kościoły na Pomorzu. Po zakończeniu działań wojennych w 1945 r. znaczna część ewakuowanego zasobu, $\mathrm{w}$ tym omawiane archiwalia proweniencji prywatnej zostały zabezpieczone przez polskich archiwistów i stały się one częścią zasobu polskiego Archiwum Państwowe w Szczecinie ${ }^{9}$. Uzupełnione zostały one o inne "poniemieckie” archiwalia prywatne i społeczne zabezpieczone przez władze polskie na ziemiach Pomorza Zachodniego w 1945 r. Wspomniane materiały w zasobie szczecińskiej placówki tworzą w znaczącej części odrębne zbiory, np. (65/11) Zbór Samuela Gottlieba von Loepera, (65/26) Archiwum rodu von ZitzewitzMuthrin itd. Część z nich jednak, zwłaszcza materiały o charakterze kolekcjonerskim i naukowym została włączona do zbioru archiwalnego (65/16) Rękopisy i Spuścizny ${ }^{10}$.

1 sierpnia 1945 r., niespełna miesiąc po ostatecznym przejęciu Szczecina przez państwo polskie, powołano Archiwum Państwowe w Szczecinie. Po okresie pionierskim (do 1950 r.), kiedy głównym zadaniem placówki było zgromadzenie zachowanych i zabezpieczonych archiwaliów "poniemieckich", Archiwum Państwowe w Szczecinie zaczęło przejmować również materiały archiwalne wytworzone już przez polskich twórców na Pomorzu Zachodnim. Zgodnie z dekretem z 29 marca 1951 r. o archiwach państwowych, a także przepisach wykonawczych, m.in. definiujących pojęcie materiałów archiwalnych i państwowego zasobu archiwalnego, szczecińskie archiwum przejmowało nie tylko dokumentację wytworzoną przez państwowe instytucje. Posiadało ono również prawo do przejmowania akt organizacji społecznych i osób prywatnych ${ }^{11}$.

Szczecińska placówka przejmowała do zasobu oprócz dokumentacji jednostek państwowych przede wszystkim archiwa organizacji społecznych: Polskiego Związku Zachodniego (1950), Ligi Lotniczej (1960), Ligi Morskiej

${ }^{9}$ Zob. Wojewódzkie Archiwum Państwowe w Szczecinie. Przewodnik po zasobie, red. H. Lesiński, Warszawa 1964, s. 18-21; M. Stelmach, Losy archiwaliów szczecińskich w okresie II wojny światowej, „Szczeciński Informator Archiwalny” 1995, nr 9. s. 17-39.

10 Archiwum Państwowe w Szczecinie. Przewodnik, s. 452-483.

11 Dekret z 29 marca 1951 r. o archiwach państwowych, Dz.U. 1951, nr 19 poz. 149; Rozporządzenie Rady Ministrów z 26 kwietnia 1952 r. w sprawie państwowego zasobu archiwalnego, Dz.U. 1952, nr 24 poz. 165; R. Górski, Archiwa osobiste. Problemy gromadzenia, opracowania i udostępniania, „Problemy Archiwistyki” 2009, nr 2, s. 23-26; tegoż, O udostępnianiu archiwaliów proweniencji prywatnej słów kilka, „Problemy Archiwistyki” 2009, nr 4, s. 1-3; A. Jabłońska, Tak zwane archiwa społeczne w Archiwum Państwowym w Szczecinie, "Szczeciński Informator Archiwalny" 2012, nr 21, s. 153-155. 
(1960), Polskiego Czerwonego Krzyża (1962) itd. ${ }^{12}$ Pierwszymi materiałami archiwalnymi prywatnymi przejętymi przez Wojewódzkie Archiwum Państwowe w Szczecinie była spuścizna Bolesława Czwójdzińskiego (1901-1972), kolejarza, pracownika Pomorskiej Dyrekcji Okręgowej Kolei Państwowych w Szczecina, ale przede wszystkim krajoznawcy, aktywnego uczestnika polonizacji Pomorza Zachodniego od 1945 r., działacza PTTK, przewodnika turystycznego, twórcy schronisk turystycznych na Pomorzu Zachodnim. Archiwalia te archiwum otrzymało w 1972 r. ${ }^{13}$

W latach siedemdziesiątych i osiemdziesiątych XX w. Wojewódzkie Archiwum Państwowe w Szczecinie wzbogaciło się jeszcze o kolejne spuścizny, m.in. nauczyciela i badacza dziejów oświaty dr. Władysława Drobnego (1900$-1989)^{14}$, artysty, historyka sztuki i pedagoga prof. Guido Recka (1919-1981) ${ }^{15}$, a przede wszystkim wybitnego pomorskiego fotografa Anatola Weczera (1902-1983), fotoreportera pracującego dla Centralnej Agencji Fotograficznej oraz wielu czasopism regionalnych i ogólnopolskich ${ }^{16}$.

Dekret z 1951 r., a przede wszystkim rozporządzenie z 1952 r. o państwowym zasobie archiwalnym traktowały bardzo szeroko to ostatnie pojęcie, włączając w nie również materiały proweniencji prywatnej, choć zastrzegając, że dotyczy to archiwaliów „po rodzinach i rodach, które odgrywały w przeszłości rolę historyczną" (par. 3. ust. 2.).

Zmiany w pojęciu archiwalia i ich rozróżnianiu na państwowe i prywatne nastąpił bardzo wyraźnie wraz z wprowadzeniem 1 stycznia 1984 r. ustawy z 14 lipca 1983 r. o narodowym zasobie archiwalnym i archiwach ${ }^{17}$. Prócz wprowadzania nowej definicji materiałów archiwalnych (art. 1.), a także narodowego zasobu archiwalnego, ustawa wprowadziła pojęcia niepaństwowego zasobu archiwalnego ewidencjonowanego i nieewidencjonowanego (art. 41.), a także je zdefiniowała (art. 42., 46.). Materiały archiwalne wytwarzane przez organizacje społeczne zostały przez ustawodawcę przypisane do

\footnotetext{
12 Wojewódzkie Archiwum Państwowe w Szczecinie. Przewodnik po zasobie, red. H. Lesiński, s. $220-225$.

13 Zespół 65/783 Spuścizna aktowa Bolesława Czwójdzińskiego, http:/ / baza.archiwa.gov. $\mathrm{pl} /$ sezam/sezam.php?l=pl\&mode=show\&zespoly_id=74120, data pobrania 1 marca $2015 \mathrm{r}$.

14 Zespół 65/990 Spuścizna aktowa Władysława Drobnego (1900-1989), http://baza.archiwa.gov.pl/sezam/sezam.php?l=pl\&mode=show\&zespoly_id=74327 [data pobrania 1 marca 2015 r.].

15 Zespół 65/1123 Spuścizna aktowa Guido Recka (1919-1981), http://baza.archiwa.gov. $\mathrm{pl} /$ sezam/sezam.php?l=pl\&mode=show\&zespoly_id=74460, data pobrania 2 marca $2015 \mathrm{r}$.

${ }^{16}$ Fotografie Anatola Weczera zostały włączone do zespołu 65/1000 Zbiór fotografii. Tworzą one w nim kilka grup tematycznych. M.in. znajdują się tu zdjęcia z wizyty I sekretarza Komunistycznej Partii Związku Radzieckiego Nikity Chruszczowa w Szczecinie w 1959 r. http://baza.archiwa.gov.pl/sezam/sezam.php?l=pl\&mode=show\&zespoly_id=74337, data pobrania 4 marca $2015 \mathrm{r}$.

17 Ustawa z 14 lipca 1983 r. o narodowym zasobie archiwalnym i archiwach, Dz.U. 1983, nr 38 poz. 173 .
} 
niepaństwowego zasobu archiwalnego ewidencjonowanego (art. 42.). Z kolei materiały archiwalne proweniencji prywatnej uznane zostały za niepaństwowy nieewidencjonowany zasób archiwalny (art. 46.) ${ }^{18}$.

Ustawa z 1983 r. określiła zakres obrotu i gromadzenia archiwaliów prywatnych (art. 47.). Według tych przepisów, właściciel materiałów archiwalnych posiada pełnię własności (art. 47. ust. 1.), ograniczoną jedynie zakazem wywozu ich zagranicę (art. 14.). Właściciel archiwaliów posiada prawo do ich sprzedaży, wymiany i darowizny (art. 47. ust. 2.). W przypadku sprzedaży ustawodawca jednak zagwarantował archiwom państwowym prawo do pierwokupu takich materiałów archiwalnych (art. 47. ust. 3., art. 9. ust. 1.) ${ }^{19}$.

Zmiana przepisów stworzyła nowy stan prawny. Państwo polskie uznało posiadanie materiałów archiwalnych przez osoby prywatne i jednocześnie uznało ich prawo do obrotu nimi. Ale przepisy te również umożliwiły archiwom państwowym większy udział w rynku archiwalnym, zwłaszcza tym komercyjnym - prawo pierwokupu.

Archiwum od drugiej połowy lat pięćdziesiątych XX w. nabywało w drodze darowizn lub kupna od osób prywatnych niewielkie akcesje dawnych archiwaliów, najczęściej pomeraników wytworzonych przed 1945 r., często z XVI-XIX w. Osoby te lub ich ascendenci najczęściej weszli w posiadanie tych materiałów w latach tuż po zakończeniu II wojny światowej, osiedlając się na Pomorzu Zachodnim. Niekiedy pośrednikiem w zakupie takich materiałów był szczeciński sklep DESA (Dzieła Sztuki i Antyki) ${ }^{20}$. Archiwum nadal nabywa niewielkie ilości archiwaliów na rynku antykwarycznym i kolekcjonerskim. Ostatnim nabytkiem (luty 2015 r.) jest kościelny rejestr opłat pogrzebowych z Darłowa z $1649 \mathrm{r}^{21}$

Przemiany polityczne i ustrojowe w Polsce przyczyniły się do wzrostu zaufania społecznego do archiwów państwowych, choć nie ujmując nic pozycji społecznej tych placówek, biblioteki, zwłaszcza uczelniane jako „mniej zależne od władzy" postrzegane były do 1989 roku za godniejsze zaufania instytucje $\mathrm{w}$ zakresie zabezpieczenia spuścizn prywatnych ${ }^{22}$. Ponadto archi-

18 Tamże, art. 46.: „Nie ewidencjonowany niepaństwowy zasób archiwalny tworzą materiały powstałe i powstające $\mathrm{w}$ wyniku działalności osób fizycznych, stanowiące własność tych osób lub ich prawnych spadkobierców".

${ }^{19}$ R. Górski, Archiwa osobiste, s. 25.

${ }^{20}$ Nabytki, jeśli udało się odtworzyć ich proweniencję, zasilały zespoły macierzyste lub włączane były do zespołu 65/16 Rękopisy i spuścizny.

${ }^{21}$ Archiwum Państwowe w Szczecinie kupiło rejestr od spadkobierców zmarłego w Koszalinie kolekcjonera broni. Posiadał on również cenną bibliotekę i wspomniany jeden rękopis pochodzący z kościoła św. Gertrudy w Darłowie. Spadkobiercy podzielili kolekcję i sprzedali ją kilku instytucjom kultury i dziedzictwa narodowego, m.in. broń białą kupiło Muzeum Oręża Polskiego w Kołobrzegu.

22 Dział rękopisów - Muzeum Literatury Książnicy Pomorskiej przejął do lat dziewięćdziesiątych XX w. kilkadziesiąt spuścizn po osobach publicznych, artystach, głównie literatach 
wa państwowe nie były aż tak zainteresowane objęciem opieką dokumentacji prywatnej, posiadając bardzo rozbudowaną strukturę jednostek państwowych i uspołecznionych przekazujących dokumentację do ich zasobów ${ }^{23}$.

Nowa sytuacja społeczna i ustrojowa, ograniczenie liczby aktotwórców państwowego zasobu archiwalnego zaowocowała wzrostem przejęć przez placówkę w Szczecinie prywatnych kolekcji i spuścizn. Już w latach dziewięćdziesiątych XX w. szczecińskie archiwum wzbogaciło się o spuścizny po profesorach Bogdanie Dopierale, Henryku Lesińskim, a przede wszystkim Piotrze Zarembie. Szczególnie ta ostatnia spuścizna stanowi ważny materiał źródłowy dla dziejów Szczecina i Pomorza Zachodniego, gdyż zawiera przede wszystkim dokumenty działalności Zaremby $\mathrm{w}$ charakterze pierwszego polskiego prezydenta Szczecina w latach 1945-1950, a także jego późniejszej aktywności społecznej i politycznej.

W następnych latach zasób szczecińskiego archiwum wzbogacił się o kolejne archiwalia proweniencji prywatnej. Od drugiej połowy lat dziewięćdziesiątych XX w. materiały o swej działalności stopniowo przekazuje pani Krystyna Łyczywek, działaczka społeczna i fotografik, pionier Szczecina ${ }^{24}$. Przekazała ona również dokumenty małżonka Romana Łyczywka (1916-1994), pierwszego polskiego adwokata w Szczecinie, który od 1945 r. prowadził praktykę prawniczą, będąc obrońcą działaczy opozycji w okresie 1945$-1989^{25}$.

Z kolei w 2001 i 2003 r. Archiwum Państwowe w Szczecinie otrzymało dwie spuścizny, bardzo istotne również dla dziejów placówki, będące dokumentacją działalności zawodowej, społecznej i naukowej dwóch wybitnych szczecińskich archiwistów prof. Mieczysława Stelmacha (1947-2000) i dr. Bogdana Frankiewicza (1923-2003). Szczególnie ta ostatnia stanowi bardzo interesujące źródło do dziejów Pomorza Zachodniego w okresie II wojny światowej, losów jeńców wojennych i robotników przymusowych w latach 1939-1945. W materiałach pozostawionych przez Frankiewicza znajdują

związanych z Pomorzem Zachodnim. Zob. C. Judek, Zbiory specjalne, w: Od Stadtbibliothek do Ksiażnicy Pomorskiej 1905-2005, Szczecin 2005, s. 91-94.

${ }^{23}$ Zmniejszenie się liczby aktotwórców przekazujących do archiwów państwowych dokumentację archiwalną w następstwie wejścia ustawy archiwalnej z 1983 r. spowodowało, iż archiwiści zaczęli zabiegać o niepaństwowych aktotwórców. A. Biernat, Prawo archiwalne w Polsce walka o nowa ustawe (ze wspomnień weterana), [w:] Archiwa polskie wczoraj i dziś, red. K. Kozłowski, W. Stępniak, Warszawa 2012, s. 27-28; W. Stępniak, Narodowy zasób archiwalny w Polsce, w: Archiwa polskie wczoraj i dziś, s. 15.

24 Pani Łyczywek (ur. 1920) nadal jest aktywną działaczką społeczną, członkiem kilku organizacji społecznych, m.in. Towarzystwa Przyjaźni Polsko-Francuskiej. Zespół 65/994 Kolekcja Krystyny Łyczywek, http://baza.archiwa.gov.pl/sezam/sezam.php?l=pl\&mode=show\&ze spoly_id=74331, data pobrania 22.04.2015.

25 Zespół 65/1357 Spuścizna aktowa Romana Łyczywka (1916-1994), http:/ / baza.archiwa. gov.pl/sezam/sezam.php?l=pl\&mode=show\&zespoly_id=74723, data pobrania 22.04.2015. 
się poza tym bardzo ciekawe materiały z okresu pionierskiego Pomorza Zachodniego (1945-1950), a także dokumenty osobiste dotyczące studiów, stypendiów zagranicznych itp. ${ }^{26}$

Z kolei w pierwszym dziesięcioleciu XXI w. Archiwum Państwowe w Szczecinie podjęło się zbierania dokumentów działaczy opozycji lat osiemdziesiątych XX w. W ramach obchodów dwudziestolecia wyborów 1989 r. (w roku 2009), a także trzydziestolecia powstania Solidarności (w roku 2010) Archiwum przygotowało szereg spotkań z działaczami Solidarności, opozycji lat siedemdziesiątych i osiemdziesiątych XX w., a także członkami OKP z 1989 r. Efektem tych spotkań była publikacja je dokumentująca, ale przede wszystkim nabytki do zasobu Archiwum Państwowego w Szczecinie, przekazane m.in. przez Włodzimierza Puzynę i Michała Paziewskiego ${ }^{27}$. Są to dokumenty obrazujące działalność ruchów opozycyjnych przed 1989 r., a także organizacji społecznych skupionych wokół Kościoła Katolickiego oraz partii politycznych po 1989 r., w tym: Ruchu Obywatelskiego Akcja Demokratyczna (ROAD), Unii Demokratycznej, Unii Wolności i Partii Demokratycznej, oraz systemu politycznego w Polsce w pierwszych latach III RP28.

Oprócz wymienionych materiałów dotyczących opozycji i działalności politycznej oraz społecznej lat osiemdziesiątych i dziewięćdziesiątych XX w. w ciągu ostatnich piętnastu lat archiwum szczecińskie przejęło kilkanaście innych zbiorów i spuścizn prywatnych. Do najważniejszych należą: depozyt rodziny Zarembów (65/1647 Zbiór dokumentów rodu Zarembów, depozyt Pawła Zaremby), a także część spuścizny prof. Alfreda Wielopolskiego, wybitnego historyka i archiwisty, przedwojennego urzędnika państwowego m.in. kancelarii prezydenta Ignacego Mościckiego, dyrektora Biura Senatu RP w 1939 r. (65/1665 Spuścizna Alfreda Wielopolskiego, 1905-1996) ${ }^{29}$.

26 Zespół 65/1503 Zbiór Bogdana Frankiewicza (1923-2003), http:/ / baza.archiwa.gov.pl/ sezam /sezam.php?l=pl\&mode=show\&zespoly_id=101721 [data pobrania 15.04.2015.]. Bogdan Frankiewicz był pionierem badań nad robotnikami przymusowymi na Pomorzu Zachodnim w okresie II wojny światowej (1939-1945). W 1969 roku opublikował monografię Praca przymusowa na Pomorzu zachodnim w latach drugiej wojny światowej (Poznań 1969).

27 Obywatelski Komitet Porozumiewawczy "Solidarność" Regionu Pomorze Zachodnie. Powstanie i działalność od marca do czerwca 1989 roku. Relacje i dokumenty, red. M. Machałek, J. Macholak, W. Puzyna, Szczecin 2014.

${ }^{28} \mathrm{~W}$ ramach akcji zbierania dokumentów dotyczących opozycji lat osiemdziesiątych XX $\mathrm{w}$. Archiwum Państwowe w Szczecinie przyjęło w latach 2009-2010 dwanaście spuścizn działaczy społecznych i politycznych tego okresu, a także przekształceń ustrojowych lat 1989-1990. A. Jabłońska, Tak zwane archizwa społeczne, s. 158-173.

${ }^{29}$ Część spuścizny prof. Alfreda Wielopolskiego przechowywana jest w zbiorach Zakładów Narodowego im. Ossolińskich we Wrocławiu. K. Kozłowski, W 80 rocznice urodzin profesora Alfreda Wielopolskiego, „Szczeciński Informator Archiwalny” 1985, nr 1, s. 11-21, http:/ / baza.archiwa.gov.pl/sezam/sezam.php?1=pl\&mode=show\&zespoly_id=166699, data pobrania 20 kwietnia $2015 \mathrm{r}$. 
W spuściznach przekazywanych do zasobu archiwum szczecińskiego oprócz dokumentacji dotyczącej działalności społecznej, politycznej, naukowej znajdują się też materiały dotyczące działalności zawodowej, pracy na stanowiskach kierowniczych. Przykładem takiej spuścizny może być (65/1493) Kolekcja Eugeniusza Kozła, pierwszego geologa województwa szczecińskiego 1955-196730. Z kolei (65/1572) Zbiór Adama Bonarskiego (1905-1980) zawiera dokumenty dotyczące pracy jego twórcy na stanowisku dyrektora Szczecińskiego Urzędu Morskiego w latach 1947-1949³1.

Napływ spuścizn działaczy społecznych, politycznych, a także naukowców, urzędników państwowych i samorządowych oraz osób prywatnych stał się też powodem do wprowadzenia w Archiwum Państwowym w Szczecinie szczegółowych procedur związanych z nabyciem i przyjęciem do zasobu wspomnianych materiałów archiwalnych oraz prawem do ich dysponowania i reprodukcji. Wypracowane zostały wzory umów nabycia materiałów archiwalnych w formie darowizny, zakupu, a także długoterminowego depozytu. Ponadto opracowano wzór umowy nabycia praw do dysponowania przez archiwum prawami autorskimi wobec przejmowanych dzieł wizualnych (filmy, zdjęcia), szczególne w zakresie prawa do ich publikacji i powielania.

Umowy te nakładają prawa i obowiązki na strony, tak archiwum, jak i osoby przekazujące archiwalia do szczecińskiej placówki. Darczyńca, sprzedający w omawianych dokumentach musi przede wszystkim potwierdzić, iż jest właścicielem przekazywanych do archiwum zbiorów, a także określić, jaki posiadają status wobec praw majątkowych wiążących się z posiadanymi archiwaliami (art. 1. ust. 1.). Następnie strony w umowie ustalają formę przekazania wspomnianych materiałów - sprzedaż, dar, depozyt (art. 1. ust. 2-3.).

Następnie w dokumencie archiwum, przejmując opisany w umowie materiał archiwalny, określa jego status w ramach zasobu placówki, np. iż będzie to zbiór archiwalnych posiadający określoną nazwę lub akta zostaną włączone do istniejącego już zespołu/zbioru archiwalnego, np. pojedyncze zdjęcia, tematy zdjęciowe włączone są do (65/1000) Zbioru fotografii Archiwum Państwowego w Szczecinie, a mapy i plany do (65/46) Zbioru kartograficznego Archiwum Państwowego w Szczecinie.

Przejmowane materiały $w$ formie daru lub zakupu na podstawie umowy zawartej między archiwum a ich dotychczasowym posiadaczem są włączane do państwowego zasobu archiwalnego. W dokumencie tym archiwum zobowiązuje się do ich zabezpieczenia i przechowywania zgodnie z normami, a także określa zakres ich udostępnienia. W umowie zawarte zostają ograni-

30 Zespół 65/1493 Kolekcja Eugeniusza Kozła, http:/ / baza.archiwa.gov.pl/sezam/sezam. php?l=pl\&mode=show\&zespoly_id=101711, data pobrania 29 kwietnia $2015 \mathrm{r}$.

31 Zespół 65/1572 Zbiór Adama Bojarskiego, http://baza.archiwa.gov.pl/sezam/sezam. php?l=pl\&mode=show\&zespoly_id=107534, data pobrania 1 maja 2015 r. 
czenia w udostępnianiu i reprodukcji archiwaliów zgłaszane przez darczyńcę bądź depozytariusza ${ }^{32}$. Ograniczenie udostępniania zostało zgłoszone w umowie przez pana Piotra Zarembę wobec zdeponowanego (65/1647) Zbioru dokumentów rodu Zarembów ${ }^{33}$.

Jak już wyżej wspomniano, przejmowane do zasobu Archiwum Państwowego w Szczecinie archiwalia od osób prywatnych są przechowywane w formie odrębnych zbiorów, kolekcji lub też włączane do istniejących już zbiorów czy kolekcji. To ostatnie działanie ma najczęściej miejsce w momencie nabywania pojedynczych dokumentów, np. zdjęć, map czy planów, plakatów lub innych druków ulotnych. Tak też najczęściej dzieje się z kupowanymi lub otrzymywanymi $\mathrm{w}$ formie darów pojedynczymi rękopisami, starymi drukami itd., które włączane są do zespołów lub zbiorów o pokrewnej proweniencji, np. rejestr pogrzebowy z Darłowa z 1649 r. został włączony do zbioru (65/43) Zbiór akt kościołów ewangelickich pomorskiej prowincji kościelnej (sygn. 335).

Archiwalia rodzinne, kolekcje, spuścizny naukowe z zasobu do $1945 \mathrm{r}$. (25 zespołów i zbiorów archiwalnych) są zbiorami i zespołami opracowanymi (załącznik nr 1). Posiadają one inwentarze książkowe wraz ze wstępami, przygotowane $\mathrm{w}$ latach siedemdziesiątych i osiemdziesiątych $\mathrm{XX}$ w. ${ }^{34}$ $\mathrm{W}$ ostatnich latach te pomoce archiwalne zostały również wprowadzone do bazy danych i udostępniane są one on line. Jednocześnie $\mathrm{w}$ ramach prac nad digitalizacją zasobu Archiwum Państwowego w Szczecinie archiwalia te zostaną w ramach projektu Polska Cyfrowa 2014-2020 zeskanowane i udostępnione on line.

Z kolei archiwa (zbiory, kolekcje, spuścizny) proweniencji prywatnej z okresu po 1945 r. (33 zespoły, zbiory), wchodzące w skład zasobu Archiwum Państwowego w Szczecinie, w przeważającej części posiadają inwentarze robocze. Część z nich stanowią już jednak zbiory opracowane, m.in. spuścizny: Mieczysława Stelmacha (65/1387), Zbigniewa Flisowskiego (65/1578), Leszka Teodozego Dąbrowskiego (65/1596), Piotra Zaremby (65/1067), Heleny Kurcyłusz (65/1355), Bogdana Frankiewicza (65/1503) oraz Henryka

32 Ponadto każda umów nabycia (sprzedaży), darowizny czy też depozytowa zawiera artykul, iż wszelkie sporne sprawy wynikające z zawieranej umowy będą rozstrzygane przed sądem pierwsze instancji właściwym dla siedziby Archiwum Państwowego w Szczecinie (art. 5.).

${ }^{33}$ Archiwalia $\mathrm{z}$ tego zbioru są udostępniane użytkownikom tylko na podstawie pisemnej zgody Piotra Zaremby.

34 Podstawą opracowania archiwaliów rodowych, majątkowych były instrukcje i wytyczne metodyczne z 1953 i 1983 r.: Instrukcja Naczelnego Dyrektora Archiwów Państwowych z 18 maja 1953 r. do porządkowania archiwaliów podworskich, [w:] Zbiór przepisów archiwalnych wydanych przez Naczelnego Dyrektora Archiwów Państwowych w latach 1952-2000, oprac. M. Tarakanowska, E. Rosowska, Warszawa 2001, s. 213-218; Pismo okólne nr 1 Naczelnego Dyrektora Archiwów Państwowych z 14 czerwca 1983 r. w sprawie wprowadzenia wskazówek metodycznych do opracowania archiwaliów podworskich, [w:] Zbiór przepisów archiwalnych, s. 487-502. 
Komarnickiego (65/1651) posiadają już inwentarze książkowe, a także elektroniczne, udostępniane on-line (załącznik $\mathrm{nr}$ 2). Opracowanie wymienionych zespołów odbywa się zgodnie z wytycznymi metodycznymi NDAP, a także z wykorzystaniem instrukcji wydanej przez Polską Akademie Nauk w 1990 r. dla opracowania spuścizn naukowych ${ }^{35}$. Również zbiory fotografii $(65 / 1000)$, plakatów (65/1001), druków ulotnych (65/1002), a także relacji i wspomnień (65/1004), choć stanowią zespoły otwarte, posiadają inwentarze książkowe i elektroniczne, które są uzupełniane o kolejne akcesje.

Archiwalia proweniencji prywatnej w Archiwum Państwowym w Szczecinie nie stanowią znaczącego udziału w całości zasobu placówki. Obejmują one niewiele więcej niż 20 tys. j.a. w prawie $1 \mathrm{mln}$ j.a. zasobu archiwum szczecińskiego (ok. $2 \%$ zasobu). Jednak ze względu na ich zawartość treściową stanowią one jednak bardzo ważne, interesujące źródło do dziejów Pomorza dawnego (od XII w.) i współczesnego, do historii państwa pruskiego, Niemiec (do 1945 r.) i Polski (od 1945 r.). Z tego też względu zasługują one na większe zainteresowanie badaczy, szczególnie zajmujących się dziejami polskiego Pomorza w XX w. Wiele interesujących materiałów źródłowych dotyczących dziejów polskiego Pomorza Zachodniego (gospodarki, społeczeństwa, polityki) zgromadzonych w spuściznach i kolekcjach (powstałych po 1945 r.) nie występuję w zespołach akt administracji państwowej, samorządowej czy też PZPR i organizacji społecznych.

${ }^{35}$ Wytyczne Archiwum Polskiej Akademii Nauk z 1990 r. do opracowania spuścizn archiwalnych po uczonych, [w:] Zbiór przepisów archiwalnych, s. 732-744. Na temat opracowania spuścizn i kolekcji m.in. R. Górski, Archiwa osobiste, s. 26-29. 


\section{Załącznik nr 1}

Wykaz zespołów i zbiorów archiwalnych akt rodowych i majątkowych, spuścizn i kolekcji naukowych i zawodowych w zasobie Archiwum Państwowego w Szczecinie do $1945 \mathrm{r}$.

Akta rodowe i majątkowe

\begin{tabular}{|c|c|c|c|c|c|}
\hline Lp. & Nr zesp. & Nazwa zespołu & $\begin{array}{l}\text { Daty } \\
\text { skrajne }\end{array}$ & $\begin{array}{l}\text { Liczba } \\
\text { j.a. }\end{array}$ & $\begin{array}{l}\text { Stan opra- } \\
\text { cowania }\end{array}$ \\
\hline 1. & $65 / 17$ & Archiwum rodu Dewitz-Wussow & $1416-1933$ & 481 & A \\
\hline 2. & $65 / 18$ & Archiwum rodu Dewitz-Messow & 1469-1901 & 701 & A \\
\hline 3. & $65 / 19$ & Archiwum rodu Dewitz-Maldewin & $1582-1828$ & 27 & A \\
\hline 4. & $65 / 20$ & Archiwum rodu Dewitz-Krebs & $1563-1901$ & 131 & A \\
\hline 5. & $65 / 21$ & Archiwum rodu Dewitz-Gantzer & $1533-1918$ & 17 & A \\
\hline 6. & $65 / 22$ & Archiwum rodu Flemmingów & $1685-1898$ & 63 & A \\
\hline 7. & $65 / 23$ & Archiwum rodu Lepelów & $1724-1792$ & 32 & A \\
\hline 8 & $65 / 24$ & Archiwum rodu Puttkammerów & $1572-1937$ & 750 & A \\
\hline 9. & $65 / 26$ & $\begin{array}{l}\text { Archiwum rodu } \\
\text { von Zitzewitz-Muthrin }\end{array}$ & $1572-1896$ & 75 & A \\
\hline 10. & $65 / 27$ & $\begin{array}{l}\text { Archiwum rodu } \\
\text { von Zitzewitz-Zezenow }\end{array}$ & $1510-1922$ & 178 & A \\
\hline 11. & $65 / 28$ & Akta dóbr Sławęcin & $1618-1888$ & 185 & A \\
\hline 12. & $65 / 29$ & Akta dóbr Buszów & $1722-1930$ & 24 & A \\
\hline 13. & $65 / 30$ & Archiwum rodu Enckevort-Vogelsang & $1641-1926$ & 282 & A \\
\hline 14. & $65 / 31$ & Archiwum rodu Podewils-Vorwerck & $1613-1921$ & 138 & A \\
\hline 15. & $65 / 32$ & Archiwum rodu Maltzahn-Utzedell & $1738-1923$ & 35 & A \\
\hline 16. & $65 / 33$ & Akta pomorskich rodów i majątków & $1555-1944$ & 172 & B \\
\hline 17. & $65 / 1340$ & Akta dóbr Kunow & 1649-1909 & 25 & A \\
\hline 18. & $65 / 1341$ & Akta dóbr Myśligoszcz & $1569-1852$ & 13 & A \\
\hline 19. & $65 / 1342$ & Akta rodziny Dohna-Schlodien & $1634-1910$ & 11 & B \\
\hline
\end{tabular}

A - zespół/zbiór opracowany; B - zespół posiada ewidencję roboczą (inwentarz roboczy)

Spuścizny i kolekcje naukowe

\begin{tabular}{|c|l|l|c|c|c|}
\hline Lp. & Nr zesp. & \multicolumn{1}{|c|}{ Nazwa zespołu } & $\begin{array}{c}\text { Daty } \\
\text { skrajne }\end{array}$ & $\begin{array}{c}\text { Liczba } \\
\text { j.a. }\end{array}$ & $\begin{array}{c}\text { Stan opra- } \\
\text { cowania }\end{array}$ \\
\hline 1. & $65 / 10$ & Zbiór Juliusza Bohlena & $1470-1884$ & 175 & $\mathrm{~A}$ \\
2. & $65 / 11$ & Zbiór Samuela Gottlieba Loepera & $1526-1790$ & 181 & $\mathrm{~A}$ \\
3. & $65 / 12$ & Spuścizna Martina Wehrmanna & $1880-1937$ & 159 & $\mathrm{~A}$ \\
4. & $65 / 13$ & Spuścizna Hansa Lutscha & $1872-1918$ & 169 & $\mathrm{~A}$ \\
5. & $65 / 14$ & Zbiór Karla Loewego & $1820-1894$ & 13 & $\mathrm{~A}$ \\
6. & $65 / 16$ & Rękopisy i spuścizny & $1321-1948$ & 1597 & $\mathrm{~A}$ \\
\hline
\end{tabular}

A - zespół/zbiór opracowany; B - zespół posiada ewidencję roboczą (inwentarz roboczy) 


\section{Załącznik nr 2}

Zbiory, kolekcje i spuścizny proweniencji prywatnej w zasobie Archiwum Państwowego w Szczecinie od 1945 r.

\begin{tabular}{|c|c|c|c|c|c|}
\hline Lp. & Nr zesp. & Nazwa zespołu & $\begin{array}{c}\text { Daty } \\
\text { skrajne }\end{array}$ & Liczba j.a. & $\begin{array}{c}\text { Stan opra- } \\
\text { cowania }\end{array}$ \\
\hline 1. & $65 / 783$ & $\begin{array}{l}\text { Spuścizna aktowa Bolesława Czwój- } \\
\text { dzińskiego (1901-1972) }\end{array}$ & $1920-1981$ & 86 & B \\
\hline 2. & $65 / 990$ & $\begin{array}{l}\text { Spuścizna aktowa Władysława } \\
\text { Drobnego (1900-1989) }\end{array}$ & $1940-1988$ & 43 & B \\
\hline 3. & $65 / 991$ & $\begin{array}{l}\text { Spuścizna aktowa Bogdana Dopierały } \\
(1922-1991)\end{array}$ & 1949-1991 & 32 & B \\
\hline 4. & 65/994 & Kolekcja Krystyny Łyczywek & $1946-2007$ & 468 & A \\
\hline 5. & $65 / 1000$ & Zbiór fotografii & $1867-2011$ & 6571 & A \\
\hline 6. & $65 / 1001$ & Zbiór plakatów i afiszy & 1849-2011 & 1165 & A \\
\hline 7. & $65 / 1002$ & Zbiór druków ulotnych & 1933-2011 & 1193 & A \\
\hline 8. & $65 / 1003$ & Zbiór nagrań & 1945-2012 & 215 & A \\
\hline 9. & $65 / 1004$ & Zbiór relacji i wspomnień & $1960-2013$ & 126 & A \\
\hline 10. & $65 / 1060$ & $\begin{array}{l}\text { Spuścizna aktowa Henryka } \\
\text { Lesińskiego (1923-1994) }\end{array}$ & 1923-1994 & 281 & B \\
\hline 11. & $65 / 1067$ & Spuścizna Piotra Zaremby (1910-1993) & $1926-1993$ & 1104 & A \\
\hline 12. & $65 / 1122$ & Zbiór akt Stefana Czarnowskiego & $1945-1971$ & 31 & B \\
\hline 13. & $65 / 1123$ & $\begin{array}{l}\text { Spuścizna aktowa Guido Recka (1919- } \\
\text {-1981) }\end{array}$ & $1948-1980$ & 30 & B \\
\hline 14. & $65 / 1355$ & $\begin{array}{l}\text { Spuścizna Heleny Kurcyusz (1914- } \\
\text {-1999) }\end{array}$ & 1939-1999 & 52 & A \\
\hline 15. & $65 / 1357$ & $\begin{array}{l}\text { Spuścizna aktowa Romana } \\
\text { Szamańskiego (1916-1994) }\end{array}$ & 1916-1994 & 259 & B \\
\hline 16. & $65 / 1387$ & $\begin{array}{l}\text { Zbiór Mieczysława Stelmacha (1947- } \\
\text {-2000) }\end{array}$ & 1962-1998 & 231 & A \\
\hline 17. & $65 / 1417$ & $\begin{array}{l}\text { Zbiór akt posła Zbigniewa } \\
\text { Szamańskiego (1938-2004) }\end{array}$ & 1981-2002 & 360 & B \\
\hline 18. & $65 / 1493$ & Kolekcja Eugeniusza Kozła & $1950-2013$ & 565 & B \\
\hline 19. & $65 / 1503$ & $\begin{array}{l}\text { Zbiór Bogdana Frankiewicza (1923- } \\
\text {-2003) }\end{array}$ & $1923-2003$ & 520 & A \\
\hline 20. & $65 / 1507$ & $\begin{array}{l}\text { Zbiór akt działaczy opozycji demokra- } \\
\text { tycznej na Pomorzu Zachodnim }\end{array}$ & 1970-1999 & 222 & B \\
\hline 21. & $65 / 1511$ & Zbiór akt Włodzimierza Puzyny & $1988-2003$ & 181 & B \\
\hline 22. & $65 / 1572$ & Zbiór Adama Bonarskiego (1905-1980) & 1946-1949 & 8 & B \\
\hline 23. & $65 / 1573$ & $\begin{array}{l}\text { Zbiór Henryka Sosnowskiego (1895- } \\
\text {-1988) }\end{array}$ & $1942-1974$ & 9 & B \\
\hline 24. & $65 / 1574$ & $\begin{array}{l}\text { Zbiór Andrzeja Leonarda } \\
\text { Palmirskiego }\end{array}$ & $1982-1993$ & 10 & B \\
\hline 25. & $65 / 1575$ & Zbiór Jana i Stanisławy Kalicińskich & 1931-1982 & 8 & B \\
\hline 26. & $65 / 1576$ & Zbiór Stanisława Bracha & $1945-1986$ & 17 & B \\
\hline
\end{tabular}




\begin{tabular}{|c|c|c|c|c|c|}
\hline Lp. & Nr zesp. & Nazwa zespołu & $\begin{array}{l}\text { Daty } \\
\text { skrajne }\end{array}$ & $\begin{array}{l}\text { Liczba } \\
\text { j.a. }\end{array}$ & $\begin{array}{l}\text { Stan opra- } \\
\text { cowania }\end{array}$ \\
\hline 27. & $65 / 1578$ & $\begin{array}{l}\text { Spuścizna Zbigniewa Flisowskiego } \\
(1923-1995)\end{array}$ & 1949-1995 & 150 & A \\
\hline 28. & $65 / 1584$ & $\begin{array}{l}\text { Spuścizna Leszka Teodozego } \\
\text { Dąbrowskiego (1912-1984) }\end{array}$ & $1965-1984$ & 93 & A \\
\hline 29. & $65 / 1605$ & $\begin{array}{l}\text { Zbiór materiałów dotyczących życia } \\
\text { społecznego }\end{array}$ & $1879-2013$ & 169 & B \\
\hline 30. & $65 / 1647$ & $\begin{array}{l}\text { Zbiór dokumentów rodu Zarembów } \\
\text { [depozyt Pawła Zaremby] }\end{array}$ & $1740-1832$ & 24 & B \\
\hline 31. & $65 / 1651$ & $\begin{array}{l}\text { Spuścizna Henryka Komarnickiego } \\
(1934-2008)\end{array}$ & $1917-2008$ & 139 & A \\
\hline 32. & $65 / 1664$ & Zbiór Anny Kolmer & $2000-2000$ & 130 & B \\
\hline 33. & $65 / 1665$ & $\begin{array}{l}\text { Spuścizna Alfreda Wielopolskiego } \\
(1905-1996)\end{array}$ & 1857-1996 & 134 & B \\
\hline
\end{tabular}

A - zespół/zbiór opracowany; B - zespół posiada ewidencję roboczą (inwentarz roboczy)

Paweł Gut

\section{Archiwa i archiwalia prywatne w zasobie Archiwum Państwowego w Szczecinie}

\section{Streszczenie}

Pierwsze archiwalia proweniencji prywatnej znalazły się w zasobie Archiwum Państwowego w Szczecinie już w 1855 r. Były to kolekcje naukowe posiadane przez Pomorskie Towarzystwo Historyczne i Archeologiczne. W 1888 r. do zasobu archiwum przekazano pierwsze archiwalia rodowe. Spuścizny i archiwa rodowe szczecińska placówka otrzymywała w formie darów lub depozytów. Do 1945 r. w zasobie Archiwum Państwowego w Szczecinie znajdowało się 50 archiwów rodzinnych oraz kilkanaście spuścizn i kolekcji.

Wiele tych materiałów zostało zabezpieczonych w 1945 r. i stało się częścią zasobu polskiego Archiwum Państwowego w Szczecinie. Od lat 70-tych XX wieku zbiera ono też archiwalia proweniencji prywatnej. Są to głównie spuścizny, zbiory i kolekcje po działaczach społecznych, naukowcach, ale też urzędnikach państwowych i politykach.

Obecnie w zasobie archiwum jest 58 archiwów, zbiorów, kolekcji i spuścizn proweniencji prywatnej (ok. 20 tys. j.a.). 


\title{
Archives and private archival materials in the National Archive in Szczecin
}

\begin{abstract}
The first archival materials of private origin were a part of the National Archive in Szczecin collection as early as 1855 . These were scientific collections owned by the Pomerania History and Archeology Association. In 1888, the first family archival materials were donated. Legacies and archives were donated or deposited. Until 1945, the Archive had possessed 50 family archives and a dozen or so legacies and collections.

Many of these materials were secured in 1945 and became a part of the Polish collection of the National Archive in Szczecin. Since the 1970s, the Archive has also collected archival materials of the private origin. These are mainly legacies and collections of social activists, scientists, public officials and politicians.

At present, there are 58 archives, collections and legacies of private origin (about 20,000 archival units) in the Archive.
\end{abstract}

